\title{
Firm Specific Variation in Returns and Fundamentals in Korea Stock Market
}

\author{
Doowon Lee \\ Newcastle Business School \\ University of Newcastle \\ University Drive, Callaghan NSW 2308, Australia \\ Email: doowon.lee@newcastle.edu.au \\ M. Kabir Hassan \\ Department of Economics and Finance \\ University of New Orleans \\ New Orleans, LA 70148, USA \\ Md. Arifur Rahman \\ School of Economics and Finance \\ University of Western Sydney \\ Locked Bag 1797, Penrith South DC \\ NSW 1797, Australia \\ Email: ar.rahman@uws.edu.au
}

Draft: May, 2009 


\title{
Firm Specific Variation in Returns and Fundamentals in Korea Stock Market
}

\begin{abstract}
This paper provides an in-depth study of the linkage between firm-specific variation in returns and fundamentals in Korea. While international studies of the emerging Asian market shows firm stock prices variation is related to their fundamentals there is a common problem of inaccuracy and lack of sufficient number of samples. We try to overcome the insufficiency of the spans of time-series data and consequent loss of statistical testing power by using firm-level micro panel data from Korean stock market. Using detailed accounting data, we test for the Fama-French 3 factor models, and see if the increasing foreign investor participation in the Korean market has effect upon the relation between stock prices and fundamentals. The results show positive correlations and significant firm-specific information incorporated in the stock price volatility. Also, firms with higher foreigner shareholder ratio, used to proxy for stock monitoring and corporate governance, seemed to show higher correlation between cash flow shocks and stock price returns volatility.
\end{abstract}

JEL classification: G14, G15, G20

Keywords: Firm-specific variation in returns, emerging stock markets, foreign investment 


\section{Introduction}

The assumed investor behavior underlying the portfolio theory, and by implication the CAPM, does not accord well with the observed investor behavior under real market conditions. For some exogenous reasons such as transaction costs, incomplete information, liquidity needs, and various institutional constraints, viz., taxes, restricted shareholding, imperfect divisibility of securities, and short sales restrictions, some investors may fail to diversify in the manner recommended by the financial theory. ${ }^{1}$ Malkiel and $\mathrm{Xu}$ (2002) have shown that when some investors are constrained to hold undiversified portfolios, the remaining investors in the market will also be unable to the hold the fully diversified market portfolio. They derive a variation of the Capital Asset Pricing Model (CAPM) that captures this phenomenon and suggests a positive relationship between idiosyncratic volatility and expected stock returns. Earlier, Levy (1978) and Merton (1987), based on similar assumptions regarding real world investor behavior, have also proposed capital market equilibrium models where rational investors are compensated with higher expected returns for bearing higher idiosyncratic volatility. A similar prediction is also extended in the behavioral asset pricing model of Barberis and Huang (2001) based on the prospect theory.

In addition to its asset pricing implications, understanding the volatility of the idiosyncratic component of asset returns is important for several other practical reasons. First, idiosyncratic volatility of returns directly affects the arbitrage activity involving individual assets. Arbitrageurs usually attempt to gain from perceived mispricing by holding portfolios that are long in one asset within an asset class and short in other assets in the same asset class. Since the combination of both long and short positions

\footnotetext{
1 Survey evidence of Huberman (2001) suggests that investors are prone to invest in familiar stocks and ignore portfolio diversification. Goetzmann and Kumar (2001) report that the majority of investors in their sample of equity investment accounts is under-diversified. More recently, Polkovnichenko (2005) also finds that many US households invest only in poorly-diversified portfolios of stocks and some households with substantial savings do not invest in equities at all.
} 
effectively removes the common component of asset returns, the risks that arbitrageurs face are related to idiosyncratic return volatility, and not aggregate market volatility. As rational traders, arbitrageurs must trade-off the risk of their position against the expected profit of the position, and therefore increased idiosyncratic volatility of asset returns may prevent them from fully taking advantage of mispricing and, as a result, larger pricing errors may continue at times of high idiosyncratic volatility (Shleifer and Vishny, 1997; Pontiff, 2006). Second, firm-level idiosyncratic volatility is important in event studies where the statistical significance of abnormal event-related returns is determined by the volatility of individual stock returns relative to that of market or industry (Campbell, Lo and MacKinlay 1997, Chapter 4). Third, one of the key factors determining option values is total volatility of the underlying asset, including idiosyncratic industry-level and firm-level idiosyncratic volatility and aggregate market volatility. Finally, from the investors' point of view, idiosyncratic volatility of individual stocks may affect the construction of portfolios to achieve the desired level of diversification. Campbell, Lettau, Malkiel and Xu (2001) note that high levels of idiosyncratic risk may be the result of low correlations between stocks and thereby increase the number of securities required to generate a well-diversified portfolio.

Even though idiosyncratic volatility of asset returns is of importance both in theory and in practice, it received only a little attention in the volatility literature at least until the end of the last century. Early research attempts such as those by Loungani, Rush and Tave (1990) and Brainard and Cutler (1993) exploit industry-specific equity return variation to test the sectoral models of reallocation which, in the tradition of Lilien (1982), imply that an increase in industry-level volatility of productivity growth may reduce output as resources are diverted from production to costly reallocation across different sectors of the economy. Beginning with Christie and Huang (1995), a few studies have also explored the behavior of firm-specific stock return variation in the analysis of herding in the stock market. Bessembinder, Chan and Seguin (1996) and Bekaert and Harvey (1997) have used some measure of cross-sectional volatility as a proxy for the firm-level information flow to the market. Roll (1992) and Heston and Rouwenhorst 
(1994) decompose world stock market volatility into industry and country-specific effects and study the implications for international portfolio diversification.

Research in idiosyncratic volatility seems to have gained momentum in recent years since the publication of a study on disaggregated volatility of US stock returns by Campbell, Lettau, Malkiel and Xu (2001). The authors decompose the return of a typical stock into three components to study the timeseries behavior of volatility of stock returns at the market, industry, and firm level and discover a puzzling phenomenon that has gone unnoticed for decades. They find that, unlike other components, the firm-level idiosyncratic volatility in the US shows a positive deterministic trend over the period from July 1962 to December 1997. The trend increase in idiosyncratic volatility relative to market volatility implies that the correlations among individual stock returns and the explanatory power of the market model for a typical stock have diminished over time. Consequently, it is also more difficult to diversify away idiosyncratic risk with a limited number of stocks in a portfolio. The findings of Campbell, Lettau, Malkiel and Xu (2001) have stimulated a series of studies searching for the potential cause(s) behind the observed pattern of volatility. In summary, the findings of these studies attribute the trend increase in US idiosyncratic volatility at the firm level to an increase in institutional involvement in equity markets (Xu and Malkiel, 2003), growth of smaller firms (Bennett and Sias, 2006), the influence of newly listed companies which are increasingly younger (Fink, Fink, Grullon and Weston, 2005), new listings by riskier companies (Brown and Kapadia, 2007), a decrease in corporate earnings and an increase in earnings volatility (Wei and Zhang, 2006), deteriorating earnings quality and higher dispersion in analysts' forecasts of earnings (Rajgopal and Venkatachalam, 2007), higher volatility of fundamental cash flow (Irvine and Pontiff, 2007), and to increasingly tougher competitive conditions in the goods market as a result of increased globalization, deregulation, and rapid technological development (Gaspar and Massa, 2006; Comin and Philippon, 2005; and Irvine and Pontiff, 2007). 
The phenomenon documented in Campbell, Lettau, Malkiel and $\mathrm{Xu}$ (2001) may also have rekindled the interest of researchers to verify the implications of idiosyncratic volatility for asset pricing as predicted in Levy (1978), Merton (1987), and Malkiel and Xu (2002). So far the empirical evidence on the relationships between idiosyncratic volatility and expected stock returns remains mixed both along the cross-sectional and time-series dimensions. For example, while Malkiel and Xu (2002), and Spiegel and Wang (2006) find that the cross-section of portfolios with higher average idiosyncratic volatility earn higher average returns, Ang, Hodrick, Xing and Zhang (2006a, 2006b) find exactly the opposite relation. Fu (2005) and Chua, Goh and Zhang (2007) study the cross-sectional relationship at the firm level and find that individual stocks with higher expected idiosyncratic volatility earn higher expected returns. On the other hand, some studies examine the intertemporal relationship between market return and aggregate, or average, idiosyncratic volatility. Goyal and Santa-Clara (2003) find that market returns are positively related to lagged average idiosyncratic volatility. However, Bali, Cakici, Yang and Zhang (2005) argue that the results of Goyal and Santa-Clara are mostly driven by small stocks traded on the NASDAQ. Guo and Savickas (2006a) show that the value-weighted idiosyncratic volatility and the market volatility jointly predict market returns (although they do not do so individually) and that idiosyncratic volatility is negatively related to future market returns. Jiang and Lee (2006) stress the need for controlling the persistence in idiosyncratic volatility and find a positive idiosyncratic risk-return tradeoff at the market level. Therefore, to date, although there is an ongoing debate as to the sign of the relationship, researchers do not seem to differ on the possibility that idiosyncratic volatility may be a priced risk factor. In summary, the existing research suggests that idiosyncratic volatility of asset returns may represent a pervasive risk factor, and that its intertemporal behavior may embody the intensity of institutional trading, information about level and volatility of corporate earnings, evolution in the structure of stock markets, and strength of the competitive forces in the economy. 
Morck, Yeung and Yu (2000) present intriguing evidence that stock returns in developed market economies tend to move in a relatively asynchronous pattern (i.e., show higher firm-specific variation) and that in emerging markets they tend to move in a relatively synchronous pattern (i.e., show lower firmspecific variation). Using data for 1995, they cannot justify the cross-country differences in firm-specific returns variation by alternative measures of firm-specific variation of stock fundamentals. Rather, they find that measures of institutional development such as good governance and stronger private property rights are significantly correlated with higher firm-specific returns variation. They suggest that poor institutions and weaker investor protections discourage informed investing in emerging markets and therefore stock prices in those economies contain little firm-specific information. These findings may have important implications because, to achieve a functionally efficient stock market where stock prices direct capital resources to their most productive uses, it is a necessary condition that changes in stock prices track firm fundamentals intimately (Tobin, 1984; Durnev, Morck, Yeung and Zarowin, 2003).

Taking a time-series perspective, Li, Morck, Yang and Yeung (2004) have recently report an important finding that, over the period from 1990 to 2001, firm-specific returns variation in most of their seventeen sample emerging markets shows a rising pattern that is at least weakly similar to the one reported by Campbell, Lettau, Malkiel and Xu (2001) for the US. They also find that firm-specific variation across those markets is significantly positively correlated with greater capital market openness and institutional development over the period. They argue that greater openness and good institutions, by facilitating better impounding of firm-specific information into stock prices, may have induced greater firm-specific variation of stock returns in those markets. More recently however, using firm-specific returns variation as a metric of the informativeness of stock prices, Chan and Hameed (2006) and Fernandes and Ferreira (2007) find either no, or even a negative, relationship between firm-specific returns variation in emerging markets and two specific measures of institutional development, namely, analysts' coverage and the 
enforcement of insider trading laws, respectively. While acknowledging the role of private information in driving firm-specific stock return variation, Roll (1988) also warns that higher firm-specific stock return variation may reflect a greater incidence of mispricing and noise trading as well. In this backdrop, it is essential that we understand the nature and the extent of the direct link between firm-specific variation of returns and firm fundamentals before interpreting the former as a gauge of the informativeness of stock prices in emerging markets.

In the wake of rising firm-specific returns variation in the US, a few studies have recently explored the link between firm-specific variations in returns and fundamentals in the US and reported significant positive relationship both along the cross-sectional and time-series dimensions (Durnev, Morck, Yeung and Zarowin, 2003; Wei and Zhang, 2006; Irvine and Pontiff, 2007). Similar crosssectional evidence for Japan is also reported in Chang and Dong (2006). However, presumably due to limited availability of accounting data, the issue has remained unaddressed so far in the context of individual emerging stock markets. Rahman and Hassan (2008) examine this phenomenon for a number of emerging Asian stock markets. We try to overcome the insufficiency of the spans of time-series data and consequent loss of statistical testing power by using firm-level micro panel data from Korean stock market, and make the first attempt to understand the link between firm-specific variations in returns and fundamentals in Korea.

\section{Data and sample selection}

\subsection{Why Korea?}

While international studies with multiple emerging markets data provides a trend or general result (see Rahman and Hassan(2008)), there is a limitation to the precision and broadness of the accounting data available when using a dataset with world wide data. For example, in depth collection of a certain stock market using domestic datasets can include more number of firms like small cap firms 
have been listed for a short time or even delisted which are likely to be excluded in world wide datasets. Indeed, while Rahman and Hassan(2008) use Worldscope and select 2315 sample firms in Korea between 1991 to 2005, this study uses over 7900 sample firms from 1992-2007. Additionally, using the Korean data provided by domestic datasets is naturally more accurate and is frequently updated.

However, using domestic datasets and increasing the sample firms is not sufficient enough to overcome the loss of generality by only focusing on one specific emerging market. Thereby, this paper adds two more features to a sample which reflects the overall market and hope to provide a further research extending the previous studies. First, we introduce two more models for the firm-specific returns volatility. In addition to CAPM model we use the Fama-French 3 factor model and the Cahart(1997) momentum factor which requires more specific market data. Second, market openness is expected to be one of the reasons why emerging Asian markets' stock prices are not devoid of their fundamentals. In Korea, foreign investors are regarded as a sophisticated investor group. We can assume that acquisition of a specific firm by foreign investors is at least a signal that the stock price reflects the fundamentals. For this reason, we check if foreign investors' ownership of a specific firm has effects upon the linkage between stock returns and fundamentals.

\subsection{Sample selection}

We use financial statement data of firms listed at the Korean Stock Exchange (KRX) retrieved from Dataguide Pro, provided by FnGuide Inc.. The date of official liberalization of the Korean Stock market was January 1992; our data coverage period starts from 1992 to the most recently available fiscal year $2007^{2}$. We included non-financial firms, firms with positive book asset to market asset ratio, and any delisted firms during the period. For precision of estimating the firm-specific variation of stock

\footnotetext{
2 Although we could use data before 1992 and analyze the difference before and after market liberalization, the 91-day Negotiable Certificate of Deposit Rate which is used as a proxy for the risk-free
} rate is only available from March 1991 thereby restricts our sample period. 
fundamentals, we use a similar selection criteria as Morck, Yeung and Yu (2000) and Durnev, Morck and Yeung(2004) by selecting firms with at least seven years of continuous financial statement data. Finally, we obtain 569 non-financial firms and 7,970 firm-year observations. Table 1 shows the number of observations per year from 1992 to 2007.

[Table 1 here]

The number of listed firms did not change much after 1992, our firm observation per year dose not change heavily even during the financial crisis. The constant number of listed firms in the KRX market might be attributed to the introduction of the Korean Securities Dealers Automated Quotations (KOSDAQ) market, which is similar to the NASDAQ market. Starting with about 200 firms in 1996, the KOSDAQ market listed firms has increased to approximately 1000 firms. The inclusion of the KOSDAQ listed firms to our sample was considered, but we decided not, after comparing the potential problem of failure to control for market differences with the small increase of observations after selecting firms with at least seven consecutive financial statement data.

Since we use all the non-financial firms available, Misalignment of financial statement data among firms due to different fiscal year end could be problematic. However, about $93.5 \%$ of the firm year observations have fiscal year ending on 31 December, the next most frequently used fiscal year end is 31 March with 3.3\%. We tested whether if using only firms with 31 December fiscal year ends could alter our results, but found that the results are qualitatively the same.

For control and robustness check purposes we require value weighted market index weekly return, foreign investors' ownership percentage of individual stock, year end market capitalization of stocks, annual trading volume of stocks, and book asset value and debt value of stocks.

\section{Firm-specific volatility Estimation}




\subsection{Firm-specific return volatility}

In our paper we use weekly stock price returns to estimate firm-specific returns volatility. Stock price data for every Wednesday (or the nearest to Wednesday if no trade occurs on Wednesday) for each stock is obtained through KSRI (Korean Securities Research Institute) dataset. We estimate yearly firmspecific returns volatility of firms with at least 10 weeks stock returns every year. In constructing firmspecific returns volatility, we use three models to control risk: i) Capital Asset Pricing Model (CAPM), ii) Fama-French 3 factor model, and iii) Fama-French 3 factor model with additional momentum factor. The CAPM model uses the market index to control market wide systematic movement of individual stock returns. The value weighted KRX market index (also known as the KOSPI index) return is used with the 91day CD rate for the risk free rate. We follow Fama and French's(1993) 3-factor model by using additional Small versus large size firms' premium (SMB), value versus growth firms' premium (HML) to the CAPM model. All the firms listed at the KRX stock market is divided into 3 portfolios by market capitalization size and 3 portfolios by book-to-market asset ratio. The SMB (HML) premium is calculated by subtracting the weekly large (low) firms' portfolio returns from the small (high) firms' portfolio returns. For the momentum factor, we use the Cahart(1997) momentum factor. Specifically, we first calculated the past 12 month to past 2 month cumulative return for all listed firms with at market price over 500 won $^{3}$. After skipping one month to account for any possibility of bid-ask bounce problems, we order the firms by their past 10 month returns. The deciles group with the highest returns is named the winner portfolio and the lowest return deciles group is named the loser portfolio. Finally, we subtract the most recent one month winner portfolio return by the loser portfolio return. The three models we use are expressed in the following equations.

$$
\text { i) } \quad r_{i, j}=\alpha_{i}+\beta_{i} r_{m, j}+\varepsilon_{i, j}^{C A P M}
$$

\footnotetext{
3 Jegadeesh and Titman(2001) exclude low stock price firms that might generate momentum profit.
} 


$$
\begin{aligned}
& \text { ii) } r_{i, j}=\alpha_{i}+b_{i} r_{m, j}+s_{i} S M B_{j}+h_{i} H M L_{j}+\varepsilon_{i, j}^{F F 3} \\
& \text { iii) } r_{i, j}=\alpha_{i}+b_{i} r_{m, j}+s_{i} S M B_{j}+h_{i} H M L_{j}+m_{i} M{ }^{\prime} m_{j}+\varepsilon_{i, j}^{F F+M o m}
\end{aligned}
$$

Where, $r_{i, j}$ is the excess returns of firm $\mathrm{i}$ in week $\mathrm{j}, r_{m, j}$ is the excess return of the market in week $\mathrm{j}, S M B_{j}$ is the small versus big firm size premium in week $\mathrm{j}, H M L_{j}$ is the value versus growth firm premium in week $\mathrm{j}$, and $\mathrm{Mom}_{j}$ is the winner versus loser firm premium in week $\mathrm{j}$. The residual $\varepsilon_{i, j}$ for each model is the firm-specific excess stock returns of firm $\mathrm{i}$ in week $\mathrm{j}$, which is used to estimate the firm-specific volatility of stock returns after controlling for systematic risks.

Since the models generate weekly firm-specific excess stock returns, the firm-specific stock returns volatility $I V_{i, t}$ for firms i and fiscal year $\mathrm{t}$ is calculated by first calculating the square of $\varepsilon_{i, j}$ for each model and adding it up for all the $\mathrm{j}$ within the same fiscal year.

$$
I V_{i, t}=\sqrt{\sum_{j=1}^{J} \varepsilon_{i, j}}
$$

\subsection{Firm-specific fundamentals volatility}

Irvine and Pontiff(2007) use the first-differences of cash flow variables to proxy shock in cash flow measures. This method is to account for strong persistence in earning related variables. The incremental value of cash flow variables are divided by the previous year's fiscal year-end stock price. To retrieve firm-specific fundamentals volatility, we use a similar model as the CAPM model. Individual firm-level cash flow shocks are regressed upon a size weighted average of cash flow shocks across firms in the same fiscal year, similar to the market index used in the CAPM models.

$$
C F S_{i, t}=\alpha_{i}+b_{i} C F S_{m, t}+e_{i, t}
$$


Where, $C F S_{i, t}$ is the cash flow shock for firm i in year t, $C F S_{m, t}$ is the size weighted cash flow shock index in fiscal year $\mathrm{t}$, and $e_{i, t}$ is the residual of the regression for firm $\mathrm{i}$ and year $\mathrm{t}$.

Assuming that the residual $e_{i, t}$ follows a Gaussian distribution, the expectation of the absolute value of the residuals is a function of the standard deviation.

$$
x \sim N\left(0, \sigma^{2}\right) \text { then } E(|x|)=\sigma \sqrt{\frac{2}{\pi}}
$$

Thereby, we follow Schwert and Seguin (1990) and estimate firm-specific fundamentals volatility using the residual $e_{i, t}$ and results from equation (5) as below.

$$
\operatorname{CFIV~}_{i, t}=\left|e_{i, t}\right| \sqrt{\frac{2}{\pi}}
$$

Using earnings data as stock fundamental, subject to managerial decisions such as smoothing earnings or shifting slightly negative earnings to positive earnings, could bias estimation of firm-specific variation. To sufficiently reflect cash flow shocks we consider i) Sales per share, ii) Cash earning per share, and iii) earnings per share as measures of cash flow. Even though we use highly reliable financial datasets, outliers or irregularities could potentially mislead firm-specific fundamentals volatility. Thereby, we winsorize our measures of cash flow by first dividing each measure by the same year-end stock prices, than replacing values above(below) the highest(lowest) $1 \%(99 \%)$ with the value equal toe the observation at the highest(lowest) 1\%(99\%). Afterwards, we multiply the year-end stock price to transform it to the original form. Figure 1 reports the firm-specific volatilities in percentage values for the sample period 1992-2007. The upper figure plots the firm-specific variations in returns estimated using the CAPM model and Fama-French 3 factor model with additional momentum factor. The lower figure plots the firm-specific variation of cash flows using sales per share (SPS), cash earnings per share (CEPS), and 
earnings per share (EPS). The sample period is 1992 to 2007 and the equally weighted cross-sectional average for each year is used for all items. The firm-specific stock returns volatility is tripled during the Asian financial crisis period but recovers to its original level within 5 years. The firm-specific fundamentals volatility show quite different characteristics. Although, the volatility sharply increases fight after the Asian financial crisis period, it is not resolved and remains high for about 5 years. The highest cash flow shocks for cash flow shocks are mainly concentrated in the year 1999-2001 when firms were recovering from the financial crisis, thereby introducing large positive shocks. Since the time each individual firms started recovering differ thorough out the market, the high volatility figures persists until 2002.

[ Figure 1 about here]

\subsection{The model}

The main issues this paper discusses, is that, the institutional reforms starting form 1992 could have shifted the Korean market to a market with more information of firm fundamentals implied in stock prices. If this statement is true, more actively reformed firms' stock return volatility should have higher dependence upon fundamental volatility. We use the average foreign investors' ownership percentage of each firm to divide the whole sample into three groups. The average foreign investor percentages of total issued shares are used to divide the total firms into terciles. The low Foreign investor group are firms with lower than $0.87 \%$ foreign investor ownership and the high foreign investor group are firms with higher than 3.5\% foreign investor ownership.

We analyze the effect of firm-specific cash flow volatility on firm-specific stock returns volatility as flowing.

$$
\log I V_{i, t}=\alpha_{i} \log I V_{i, t-1}+\beta_{i} \log C F I V_{i, t}+\delta_{t}+\eta_{i}+\varepsilon_{i, t}
$$

Where $\log I V_{i, t}$ is the logarithmic value of stock returns volatility for firm i and fiscal year $\mathrm{t}$, 
$\log C F I V_{i, t}$ is the logarithmic value of cash flows volatility for firm i and fiscal year t, $\delta_{t}$ is the timespecific effects, and $\eta_{i}$ is the time invariant firm-specific effect for firm $\mathrm{i}$.

While we can account for time-specific effects by using time dummies, it is problematic to estimate equation (7) without an exact measure of knowledge of individual firm-specific effect. For example, errors in variables problem could bias the regression coefficients. Also, the endogenous properties of certain repressors, like $\log C F I V_{i, t}$ in our model, can cause problems. Thereby, we follow Arellano and Bond(1991), Arellano and Bover (1995), and Blundell and Bond(1998) and introduce the system GMM methodology. First, the simple first order difference of equation (7) is used to remove any time invariant variables. Changing equation (7) to the differenced equation (8) is shown below.

$$
\Delta \log I V_{i, t}=\alpha_{i} \Delta \log I V_{i, t-1}+\beta_{i} \Delta \log C F I V_{i, t}+\Delta \delta_{t}+\Delta \varepsilon_{i, t}
$$

While equation (8) kills off any time invariant variables, additional endogeneity of $\log I V_{i, t-1}$

and the residual $\varepsilon_{i, t-1}$ in equation (8) is generated. Also, the pre-existing endogeneity of $\log C F I V_{i, t}$ has to be considered. Since the endogenous variables are at most correlated to one time lagged residuals, we follow Hassan and Rahman (2008) and use instrument variables for repressors and two time lagged residuals as follows.

$$
E\left[\begin{array}{c}
\log I V_{i, t-s} \Delta \varepsilon_{i, t} \\
\log C F I V_{i, t-s} \Delta \varepsilon_{i, t}
\end{array}\right]=\left[\begin{array}{l}
0 \\
0
\end{array}\right] \text { for } \mathrm{s} \geq 2
$$

We test for the orthogonality of the instruments by providing the Hansen statistics for over identifying restrictions. Also, the autocorrelation must not exist further that the first lag. Therefore, we test the existence of any serial autocorrelation at the second lagged residuals. In condition (9) the length of lagged variables and residuals can be as long as the individual firm observation length minus one (since the first difference is used). However, more lagged variables might cause over fit and 
computational inefficiency. Thereby, we only use the lags of repressors up to the level with the lowest Hansen statistics available without over identifying the moment conditions.

Another set of instrumental variables can be tested by assuming lagged differences are not correlated with firm specific effects.

$$
E\left[\begin{array}{c}
\Delta \log I V_{i, t-s}\left(\eta_{t}+\varepsilon_{i, t}\right) \\
\Delta \log C F I V_{i, t-s}\left(\eta_{t}+\varepsilon_{i, t}\right)
\end{array}\right]=\left[\begin{array}{l}
0 \\
0
\end{array}\right] \text { for } \mathrm{s} \geq 1
$$

The second set of moment conditions are based on assumptions, so we test the validity of additional instruments under the null hypothesis that our assumption is plausible. The "difference in Hansen" statistics proposed by Hansen (1982) is reported.

To check if firm-specific return volatility is still related to firm-specific fundamentals volatility after controlling for additional variables noted to be related to stock returns volatility, we include trading volume, firm size, leverage, and growth opportunity in equation (8). Previous literatures note that trading volume is positively related to stock returns, so we use the average trading volume divided by outstanding shares as a proxy of trading volume $\left(T R_{i, t}\right)$. Malkiel and $\mathrm{Xu}(2003)$ suggest that higher future growth opportunity (lower book-to-market ratio) is related to greater stock return volatility, while firm size is likely to be negatively related to stock returns volatility. Therefore, we use the lagged market capitalization $\left(\right.$ Size $\left._{i, t-1}\right)$ and lagged book to market ratio $\left(B M_{i, t-1}\right)$ of each firms and expect both variables to have negative correlation. Finally, Chang and Dong(2006) include the lagged return variable $\left(R T N_{i, t-1}\right)$ to account for the negative relationship between stock returns and volatility. The robustness check modified regression is as below.

$$
\begin{aligned}
& \Delta \log I V_{i, t}=\alpha_{i} \Delta \log I V_{i, t-1}+\beta_{i} \Delta \log C F I V_{i, t}+ \\
& \gamma_{1, i} \Delta \log T R_{i, t}+\gamma_{2, i} \Delta \log \operatorname{Size}_{i, t-1}+\gamma_{3, i} \Delta B M_{i, t-1}+\gamma_{4, i} \Delta R T N_{i, t-1}+\Delta \delta_{t}+\Delta \varepsilon_{i, t}
\end{aligned}
$$




\section{Analysis of Results}

In this section we discuss the summary statistics and main results of this paper. The descriptive statistics of variables used in this paper is presented in table 2. The firm-specific volatilities are presented in percentage values. CAPM, FF3, FF3+Mom each represent firm-specific variation of stock returns measured using Capital Asset Pricing Model, Fama-French 3 factor model, and Fama-French 3 factor model with additional momentum factor. CFIV(SPS), CFIV(CEPS), CFIV(EPS) denote measures of firmspecific variation of cash flows using sales per share (SPS), cash earnings per share (CEPS), and earnings per share (EPS), respectively. The control variables TR, $\log (\operatorname{Size}), \mathrm{B} / \mathrm{M}, \mathrm{RTN} \%$, foreign $\%$ denote turnover ratio, lagged log of firm market capitalization, lagged book-to-market ratio, lagged stock price yearly return in percentage, and lagged foreign investor ownership in percentage. The coefficient of variation is defined as the ratio of the standard deviation to the mean of each variable. As discussed in the previous section, Panel B to Panel D is the statistics for the average foreign shareholder percentage terciles.

[Table 2 here]

Firm-specific variation of stock returns is lower when controlling for additional risk factors compared to CAPM model, also the FF3 average is slightly higher than FF3+Mom values. Different foreign shareholder group results show higher shareholder percentage firms generally has lower firmspecific volatility of stock returns. Among the alternative measure of firm-specific fundamentals volatility, SPS is has the highest value followed by EPS then CEPS. The values for foreign investors' tercile groups for fundamental volatilities have similar patterns to stock return volatility. The control variables do not show strong patterns among different tercile groups, except for the market capitalization size. It seems 
that foreign investors could have higher ownership in big firms due to more acknowledgement and liquidity of such firms.

[Table 3 here]

Table 3 presents the correlation matrix of variables used in this paper. Most of the variables are transformed into log values for our estimation model. Firm-specific stock returns volatility values for all sample firms show rather high correlation, especially the FF3 model and FF3+Mom values have a near 1 correlation. Henceforth we only consider the CAPM and FF3+Mom for the main results. Firm-specific fundamental volatility also has positive correlation near 0.4 for SPS, which can be considered as the most indirect measure related to earning in our analysis. The correlation for CEPS and EPS is about 0.616. The third correlation matrix provides evidence of fairly high correlation between the stock returns volatilities and fundamental volatilities. Although not provided, we find that higher correlation coefficients are achieved for the higher foreign investors' group. Finally, the correlation matrix for the control variables and the firm-specific stock returns volatility has the same values that are expected and discussed in the previous section. Only the logarithmic value of turnover ratio has positive correlation, while the rest have negative values.

[Table 4 here]

Table 4 reports the results of the two-step System-GMM estimation for log values of firmspecific variations in stock returns (log IV) estimated using the CAPM model. The regression results of using separate cash flow shocks measured by SPS, CEPS, and SPS are show in each panel. Again, each panel is divided into three groups depending on the average foreign investors' ownership percentage. Finally, for each foreign investor group, we provide the simple regression results using equation (8) and robustness check regression using equation (11).

The lagged firm-specific stock return volatility has positive values with the minimum coefficient value at 0.285 . All the coefficients are statistically significant at the $1 \%$ level, showing that 
firm-specific stock return volatilities have somewhat persistent features. The CFIV coefficients are significant at $1 \%$ level for all measure of firm-specific fundamental volatilities. Although no statistics exist for comparing different foreign investors groups' coefficients, CEPS and EPS results show higher foreign investors percentage is followed by higher CFIV coefficients. The mixed of decreasing coefficients related to increasing foreign ownership might be because SPS is not a direct measure of firms earnings. For a closer inspection, we added additional control variables such as turnover ratio (log TR), firm size (log Size), leverage effect (RTN), and book-to-market (B/M). Most of the coefficients of control variables are as expected, except for lagged year end return variable, which shows no significance with positive values. After adding control variables, the magnitude of CFIV coefficients have slightly decreased but still significant at $1 \%$ level. The ordering of CFIV coefficients for panel B and C from low foreign investor ownership to high ownership is exactly the same. However, panel A using SPS still shows mixed ordering among ownership groups.

In table 4 we also provide statistics for the validity of our model. As mentioned in the previous section, the autocorrelation test for first and second order autocorrelation in the residuals of the differenced equations are reported. The p-values of the first order autocorrelation for all nine regressions in table 4 are smaller than $1 \%$, while the second order autocorrelation p-values are above $10 \%$ level. The statistics from table 4 confirms that the models we use are well specified in the usage of endogenous repressors. The Hansen and difference in Hansen test statistics are also provided to check for over identification of restrictions for system-GMM estimation and additional moment conditions. The statistics can not reject the null-hypothesis of the validity of moment conditions in all nine regressions. Another aspect we checked was the number of instrument variables. Roodman (2006) suggest that a perfect Hansen statistic of 1.000 can be signs of endogenous variables being over fit. In our analysis the numbers of instruments are about $10 \%$ of the observations used and the Hansen statistics are mostly in the range of 0.1 to 0.7 . Overall, our results align with the results that fundamental volatility has notable relation with 
stock returns volatility in an open stock market.

The rest of this section checks if using CAPM model is sufficient for measuring firm-specific stock return volatility. During a period of market alteration, firms tend to show increased idiosyncratic stock returns as plotted in figure 1. We control for additional firm related risks using the FF3+Mom model and see if the results in table 4 hold. Table 5 is the results with the same panel and group classification. The main result does not change. Most of the coefficients are significant at $1 \%$ level. CFIV coefficients for CEPS and EPS have the same order as the foreign ownership order. The only difference is that the CFIV coefficients ordering after controlling for turnover ratio, size, return and B/M has changed to have an increasing value. The autocorrelation tests and over identification tests are quantitatively the same as table 4.

[Table 5 here]

\section{Concluding remarks}

Stock price in emerging markets have been considered to lack sufficient information of firmspecific information. However, recent study by Li, Morck, Yang, and Yeung (2004) suggest that increasing market openness has increased firm-specific stock return volatility in most of the emerging markets. Since most of the emerging Asian markets faced stock market liberalization during the early 1990s, we could expect stock prices to reflect firm-specific information. We use the simple present value of expected future cash flows to find evidence of existing relation between firms' specific information and stock price changes in the Korean stock market. The Korean stock market is one of the most opened stock market in Asia, with foreign investments summing up to almost $40 \%$ of total market capitalization.

The most direct earnings per share and less direct cash earning per share and sales per share are used to measure firm-specific variation of cash flow fundamentals. Also, diverse models such as CAPM and Fama and French 3 factor models were used to estimate firm-specific stock return variation. To reflect the level of stock openness, we divide our sample into low, medium, and high foreign investors' 
ownership groups. The results show positive correlations and significant firm-specific information incorporated in the stock price volatility. Also, firms with higher foreigner shareholder ratio, used to proxy for stock monitoring and corporate governance, seemed to show higher correlation between cash flow shocks and stock price returns volatility. A limitation of our approach is that strong significant level of firm-specific cash flow shock, however, does not represent the amount of information in stock prices. 


\section{References}

Arellano, M., Bond, S., 1991. Some tests of specification for panel data: Monte Carlo evidence and an application to employment equations. The Review of Economic Studies 58(2), 277-297.

Arellano, M., Bover, O., 1995. Another look at the instrumental variable estimation of error-component models, Journal of Econometrics 68, 29-51.

Blundell, R., Bond, S., 1998. Initial conditions and moment restrictions in dynamic panel data models. Journal of Econometrics 87, 115-143.

Campbell, J.Y., Lettau, M., Malkiel, B.G., Xu, Y., 2001. Have individual stocks become more volatile? An empirical exploration of idiosyncratic risk. Journal of Finance 56, 1-43.

Chang, E.C., Dong, S., 2006. Idiosyncratic volatility, fundamentals, and institutional herding: Evidence from the Japanese stock market. Pacific-Basin Finance Journal 14, 135-154.

Durnev, A., Morck, R., Yeung, B., Zarowin, P., 2003. Does greater firm-specific return variation mean more or less informed stock pricing?. Journal of Accounting Research 41, 797-836.

Durnev, A., Morck, R., Yeung, B., 2004. Value-enhancing capital budgeting and firm-specific stock return variation. Journal of Finance 59, 65-105.

Durnev, A., Li, K., Morck, R., Yeung, B., 2004. Capital markets and capital allocation: Implications for economies in transition. Economics of Transition 12(4), 593-634.

Fama, Eugene F., and Kenneth R. French, 1993, Common risk factors in the returns on bonds and stocks, Journal of Financial Economics 33, 3-53.

Fama, Eugene F., and Kenneth R. French, 1996, Multifactor explanations of asset pricing anomalies, Journal of Finance 51, 55-84.

Fama, E.F., MacBeth, J.D., 1973. Risk, return, and equilibrium: Empirical tests. Journal of Political Economy 81, 607-636.

Fox, M.B., Morck, R., Yeung, B., Durnev, A., 2003. Law, share price accuracy, and economic performance: The new evidence. Michigan Law Review 102(3), 331-386.

Griliches, Z., Hausman, J., 1986. Errors in variables in panel data. Journal of Econometrics 31(1), 93-118.

Hansen, L., 1982. Large sample properties of generalized method of moments estimators. Econometrica 50, 1029-1054.

Hassan, K., Rahman, A., 2008, Firm-specific variations in returns and fundamentals in emerging Asian stock markets, working paper

Irvine, P.J., Pontiff, J., 2007. Idiosyncratic return volatility, cash flows, and product market competition. Review of Financial Studies, Forthcoming.

Jegadeesh, N., and Titman, S., 1993, Returns to buying winners and selling losers: Implications for stock market efficiency, Journal of Finance 48, 65-91.

Jegadeesh, N., and Titman, S., 1995, Overreaction, delayed reaction, and contrarian profits, Review of Financial Studies 8, 973-994. 
Jegadeesh, N., and Titman, S., and Sheridan Titman, 2001, Profitability of momentum strategies: An evaluation of alternative explanations, Journal of Finance 56, 699-720.

Li, K., Morck, R., Yang, F., Yeung, B., 2004. Firm-specific variation and openness in emerging markets. Review of Economics and Statistics 86(3), 658-669.

Mark M. Cahart, 1997, On Persistence in Mutual Fund Performance, The Journal fo Finance 52(1), 57-82

Morck, R., Yeung, B., Yu, W., 2000. The information content of stock markets: Why do emerging markets have synchronous price movements?. Journal of Financial Economics 58, 215-260.

Pagan, A.R., 1984. Econometric issues in the analysis of regressions with generated regressors. International Economic Review 25, 221-247.

Pagan, A.R., Ullah, A., 1988. The econometric analysis of models with risk terms. Journal of Applied Econometrics 3, 87-105.

Petersen, M., 2007. Estimating standard errors in finance panel data sets: Comparing approaches. Working Paper. Northwestern University.

Rajgopal, S., Venkatachalam, M., 2007. Financial reporting quality and idiosyncratic return volatility over the last four decades. Working Paper. Duke University.

Roll, R., 1988. 2R. Journal of Finance 43, 541-566.

Roodman, D., 2004. The anarchy of numbers: Aid, development, and cross-country empirics. Working Paper 32. Center for Global Development, Washington DC.

Roodman, D., 2006. How to do xtabond2: An introduction to "difference" and "system GMM in Stata. Working Paper 103. Center for Global Development, Washington DC.

Sargan, J., 1958. The estimation of economic relationships using instrumental variables. Econometrica 26(3), 393-415.

Schwert, G.W., Seguin, P.J., 1990. Heteroskedasticity in stock returns. Journal of Finance 45, 1129-1156. 
Figure 1. Yearly firm-specific variations in returns and cash flows
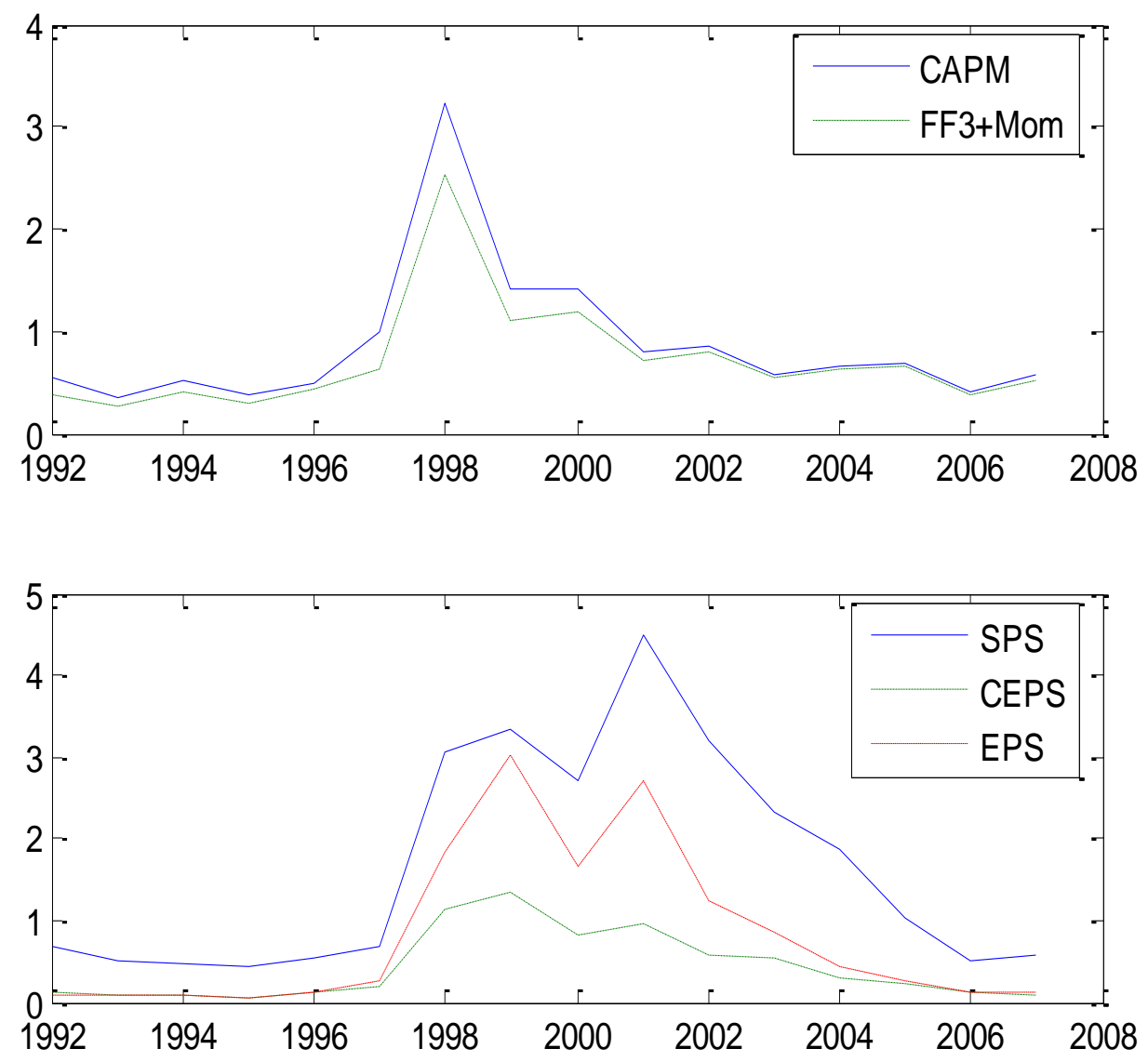

The upper figure plots the firm-specific variations in returns estimated using the CAPM model and FamaFrench 3 factor model with additional momentum factor. The lower figure plots the firm-specific variation of cash flows using sales per share (SPS), cash earnings per share (CEPS), and earnings per share (EPS). The sample period is 1992 to 2007 and the equally weighted cross-sectional average for each year is used for all items. 
Table 1. Number of firm observations per year

\begin{tabular}{ccc}
\hline Year & Firms & Percent \\
1992 & 426 & 5.35 \\
1993 & 441 & 5.53 \\
1994 & 445 & 5.58 \\
1995 & 453 & 5.68 \\
1996 & 474 & 5.95 \\
1997 & 499 & 6.26 \\
1998 & 533 & 6.69 \\
1999 & 557 & 6.99 \\
2000 & 553 & 6.94 \\
2001 & 551 & 6.91 \\
2002 & 536 & 6.73 \\
2003 & 524 & 6.57 \\
2004 & 511 & 6.41 \\
2005 & 493 & 6.19 \\
2006 & 489 & 6.14 \\
2007 & 485 & 6.09 \\
\hline Total & 7,970 & 100 \\
\hline
\end{tabular}

Table 1 shows the number of firms each year used in this paper. We use non-financial firms listed at the Korean Stock Exchange during 1992- 2002. Firms with at least 7 consecutive financial statement data and stock price data are selected. 
Table 2. Summary statistics of firms-specific variations in stock returns and fundamentals

Panel A. Statiatics of Full Sample

\begin{tabular}{|c|c|c|c|c|c|c|c|c|c|c|c|}
\hline & CAPM & FF3 & FF3+Mom & CFIV(SPS) & CFIV(CEPS) & CFIV(EPS) & TR & $\log ($ size $)$ & $\mathrm{B} / \mathrm{M}$ & RTN \% & foreign $\%$ \\
\hline Mean & 0.896 & 0.743 & 0.742 & 1.745 & 0.453 & 0.877 & 4.780 & 10.800 & 1.146 & 0.214 & 5.336 \\
\hline $25 \%$ & 0.291 & 0.247 & 0.247 & 0.240 & 0.056 & 0.055 & 1.093 & 9.785 & 0.904 & -0.306 & 0.000 \\
\hline $50 \%$ & 0.489 & 0.408 & 0.407 & 0.554 & 0.142 & 0.156 & 2.364 & 10.591 & 1.081 & -0.012 & 0.158 \\
\hline $75 \%$ & 1.005 & 0.819 & 0.823 & 1.260 & 0.338 & 0.382 & 4.749 & 11.618 & 1.325 & 0.388 & 4.293 \\
\hline Coef. Of Variation & 1.235 & 1.206 & 1.207 & 3.603 & 3.695 & 4.913 & 2.615 & 0.143 & 0.372 & 5.916 & 2.165 \\
\hline
\end{tabular}

Panel B Statiatics of Firms within the Lowest Tercile of Average Foreign Shareholder Percentage

\begin{tabular}{cccccccccccccc} 
& CAPM & FF3 & FF3+Mom & CFIV(SPS) & CFIV(CEPS) & CFIV(EPS) & TR & $\log ($ size) & B/M & RTN \% & foreign \% \\
\hline Mean & 1.148 & 0.922 & 0.921 & 1.932 & 0.558 & 1.142 & 5.831 & 9.887 & 1.143 & 0.204 & 0.318 & 0.062 \\
$25 \%$ & 0.375 & 0.296 & 0.294 & 0.224 & 0.062 & 0.064 & 1.482 & 9.234 & 0.897 & -0.358 & 0.000 \\
$50 \%$ & 0.668 & 0.520 & 0.515 & 0.564 & 0.160 & 0.176 & 3.215 & 9.868 & 1.078 & -0.060 & 0.008 \\
$75 \%$ & 1.390 & 1.111 & 1.103 & 1.296 & 0.384 & 0.489 & 5.928 & 10.511 & 1.326 & 0.345 & 0.173 \\
Coef. Of Variation & 1.138 & 1.138 & 1.140 & 4.058 & 3.681 & 4.867 & 2.098 & 0.101 & 0.391 & 6.896 & 2.790
\end{tabular}

Panel C. Statiatics of Firms within the Middle Tercile of Average Foreign Shareholder Percentage

\begin{tabular}{|c|c|c|c|c|c|c|c|c|c|c|c|}
\hline & CAPM & FF3 & FF3+Mom & CFIV(SPS) & CFIV(CEPS) & CFIV(EPS) & $\mathrm{TR}$ & $\log ($ size $)$ & $\mathrm{B} / \mathrm{M}$ & RTN \% & foreign $\%$ \\
\hline Mean & 0.895 & 0.739 & 0.738 & 1.967 & 0.500 & 0.991 & 5.500 & 10.622 & 1.188 & 0.194 & 1.978 \\
\hline $25 \%$ & 0.295 & 0.247 & 0.246 & 0.272 & 0.057 & 0.057 & 1.171 & 9.920 & 0.929 & -0.315 & 0.000 \\
\hline $50 \%$ & 0.504 & 0.410 & 0.412 & 0.632 & 0.154 & 0.165 & 2.560 & 10.559 & 1.111 & -0.017 & 0.199 \\
\hline $75 \%$ & 0.992 & 0.798 & 0.803 & 1.500 & 0.366 & 0.404 & 5.094 & 11.328 & 1.369 & 0.371 & 2.578 \\
\hline Coef. Of Variation & 1.209 & 1.189 & 1.191 & 2.934 & 3.675 & 4.628 & 2.721 & 0.106 & 0.375 & 5.594 & 1.799 \\
\hline \multicolumn{12}{|c|}{ Panel D. Statiatics of Firms within the Highest Tercile of Average Foreign Shareholder Percentage } \\
\hline & CAPM & FF3 & FF3+Mom & CFIV(SPS) & CFIV(CEPS) & CFIV(EPS) & TR & $\log ($ size $)$ & $\mathrm{B} / \mathrm{M}$ & RTN \% & foreign $\%$ \\
\hline Mean & 0.649 & 0.570 & 0.570 & 1.342 & 0.302 & 0.502 & 3.031 & 11.876 & 1.106 & 0.243 & 13.609 \\
\hline $50 \%$ & 0.375 & 0.334 & 0.330 & 0.483 & 0.115 & 0.133 & 1.648 & 11.704 & 1.054 & 0.044 & 6.727 \\
\hline $75 \%$ & 0.684 & 0.594 & 0.595 & 1.040 & 0.285 & 0.303 & 3.169 & 12.814 & 1.283 & 0.429 & 21.689 \\
\hline Coef. Of Variation & 1.273 & 1.213 & 1.210 & 3.638 & 2.947 & 3.835 & 3.151 & 0.142 & 0.341 & 5.268 & 1.228 \\
\hline
\end{tabular}

Table 2 presents the descriptive statistics of variables used in this paper.. CAPM, FF3, FF3+Mom each represent firm-specific variation of stock returns measured using Capital Asset Pricing Model, Fama-French 3 factor model, and Fama-French 3 factor model with additional momentum factor. CFIV(SPS), CFIV(CEPS), CFIV(EPS) denote measures of firm-specific variation of cash flows using sales per share (SPS), cash earnings per share (CEPS), and earnings per share (EPS), respectively. The control variables TR, $\log ($ Size $), \mathrm{B} / \mathrm{M}, \mathrm{RTN} \%$, foreign \% denote turnover ratio, lagged log of firm market capitalization, lagged book-to-market ratio, lagged stock price yearly return in percentage, and lagged foreign investor ownership in percentage. The coefficient of variation is defined as the ratio of the standard deviation to the mean of each variable. 
Table 3. Correlation matrix

\begin{tabular}{cccc}
\hline & $\log$ CAPM & $\log$ FF3 & $\log$ FF3+Mom \\
\cline { 2 - 4 } $\log$ CAPM & 1.000 & & \\
$\log$ FF3 & 0.978 & 1.000 & \\
$\log$ FF3+Mom & 0.977 & 0.999 & 1.000 \\
& & & \\
& & & \\
\cline { 2 - 4 } $\log$ CFIV(SPS) & $\log$ CFIV(CEPS) & $\log$ CFIV(EPS) \\
\cline { 2 - 4 } $\log$ CFIV(SPS) & 1.000 & & \\
$\log$ CFIV(EPS) & 0.435 & 1.000 & \\
& 0.409 & 0.616 & 1.000 \\
& & & \\
$\log$ CFIV(SPS) & 0.299 & 0.312 & 0.313 \\
$\log$ CFIV(CEPS) & 0.399 & 0.410 & 0.411 \\
$\log$ CFIV(EPS) & 0.445 & 0.458 & 0.459 \\
& & & \\
& $\log$ CAPM & $\log$ FF3 & $\log$ FF3+Mom \\
\cline { 2 - 4 } $\log$ TR & 0.523 & 0.498 & 0.497 \\
$\log$ size & -0.407 & -0.377 & -0.377 \\
RTN & -0.016 & -0.004 & -0.005 \\
B/M & -0.177 & -0.148 & -0.147 \\
\hline
\end{tabular}

Table 3 presents the correlation matrix of variables used in this paper. Log CAPM, log FF3, log FF3+Mom each represent the log value of firm-specific variation of stock returns measured using Capital Asset Pricing Model, Fama-French 3 factor model, and Fama-French 3 factor model with additional momentum factor. Log CFIV(SPS), log CFIV(CEPS), log CFIV(EPS) denote log measures of firmspecific variation of cash flows using sales per share (SPS), cash earnings per share (CEPS), and earnings per share (EPS), respectively. The control variables $\log$ TR, $\log$ Size, RTN, B/M, foreign \% denote $\log$ turnover ratio, lagged log of firm market capitalization, lagged stock price yearly return, lagged book-tomarket ratio, and lagged foreign investor ownership. 
Table 4. Firm-specific variations in returns and fundamentals using CAPM Model

\begin{tabular}{|c|c|c|c|c|c|c|}
\hline \multicolumn{7}{|c|}{ Panel A: IV measured using CAPM Model - SPS } \\
\hline & \multicolumn{2}{|c|}{ Low Foreign } & \multicolumn{2}{|c|}{ Mid Foreign } & \multicolumn{2}{|c|}{ High Foreign } \\
\hline $\log \operatorname{IV}(\mathrm{t}-1)$ & $\begin{array}{c}0.285 * * * \\
(0.033)\end{array}$ & $\begin{array}{c}0.178 * * * \\
(0.040)\end{array}$ & $\begin{array}{c}0.312 * * * \\
(0.037)\end{array}$ & $\begin{array}{c}0.166 * * * \\
(0.039)\end{array}$ & $\begin{array}{c}0.306 * * * \\
(0.035)\end{array}$ & $\begin{array}{c}0.233 * * * \\
(0.037)\end{array}$ \\
\hline $\log$ CFIV & $\begin{array}{c}0.222 * * * \\
(0.031)\end{array}$ & $\begin{array}{c}0.133 * * * \\
(0.029)\end{array}$ & $\begin{array}{c}0.155 * * * \\
(0.040)\end{array}$ & $\begin{array}{c}0.144 * * * \\
(0.034)\end{array}$ & $\begin{array}{c}0.154 * * * \\
(0.032)\end{array}$ & $\begin{array}{c}0.122 * * * \\
(0.027)\end{array}$ \\
\hline $\log \mathrm{TR}$ & & $\begin{array}{c}0.151 * * * \\
(0.031)\end{array}$ & & $\begin{array}{c}0.241 * * * \\
(0.033)\end{array}$ & & $\begin{array}{c}0.238 * * * \\
(0.039)\end{array}$ \\
\hline $\log$ Size & & $\begin{array}{c}-0.191 * * * \\
(0.028)\end{array}$ & & $\begin{array}{c}-0.151 * * * \\
(0.027)\end{array}$ & & $\begin{array}{c}-0.086 * * * \\
(0.013)\end{array}$ \\
\hline RTN & & $\begin{array}{c}0.014 \\
(0.023)\end{array}$ & & $\begin{array}{c}0.019 \\
(0.018)\end{array}$ & & $\begin{array}{c}0.01 \\
(0.007)\end{array}$ \\
\hline $\mathrm{B} / \mathrm{M}$ & & $\begin{array}{c}-0.302 * * * \\
(0.060)\end{array}$ & & $\begin{array}{c}-0.179 * * \\
(0.072)\end{array}$ & & $\begin{array}{l}-0.061 \\
(0.045)\end{array}$ \\
\hline Time effect & Yes & Yes & Yes & Yes & Yes & Yes \\
\hline$\overline{\mathrm{AR}(1)}$ & 0.000 & 0.000 & 0.000 & 0.000 & 0.000 & 0.000 \\
\hline $\mathrm{AR}(2)$ & 0.910 & 0.449 & 0.349 & 0.782 & 0.992 & 0.613 \\
\hline Hansen & 0.154 & 0.236 & 0.211 & 0.229 & 0.237 & 0.335 \\
\hline Diff-Hansen & 0.668 & 0.737 & 0.738 & 0.624 & 0.899 & 0.256 \\
\hline Instruments & 143 & 177 & 163 & 177 & 121 & 177 \\
\hline Firms & 190 & 190 & 189 & 189 & 190 & 190 \\
\hline Firm-years & 2456 & 2456 & 2456 & 2456 & 2489 & 2489 \\
\hline & Panel & IV meas & using $\mathrm{CAl}$ & Model - & & \\
\hline & Low 1 & reign & Mid & reign & High & reign \\
\hline $\log \operatorname{IV}(\mathrm{t}-1)$ & $\begin{array}{c}0.335 * * * \\
(0.035)\end{array}$ & $\begin{array}{c}0.177 * * * \\
(0.041)\end{array}$ & $\begin{array}{c}0.305 * * * \\
(0.036)\end{array}$ & $\begin{array}{c}0.174 * * * \\
(0.036)\end{array}$ & $\begin{array}{c}0.329 * * * \\
(0.036)\end{array}$ & $\begin{array}{c}0.250 * * * \\
(0.035)\end{array}$ \\
\hline $\log$ CFIV & $\begin{array}{c}0.173 * * * \\
(0.027)\end{array}$ & $\begin{array}{c}0.094 * * * \\
(0.031)\end{array}$ & $\begin{array}{c}0.187 * * * \\
(0.042)\end{array}$ & $\begin{array}{c}0.131 * * * \\
(0.031)\end{array}$ & $\begin{array}{c}0.198 * * * \\
(0.039)\end{array}$ & $\begin{array}{c}0.150 * * * \\
(0.033)\end{array}$ \\
\hline $\log \mathrm{TR}$ & & $\begin{array}{c}0.178 * * * \\
(0.031)\end{array}$ & & $\begin{array}{c}0.186 * * * \\
(0.035)\end{array}$ & & $\begin{array}{c}0.249 * * * \\
(0.039)\end{array}$ \\
\hline $\log$ Size & & $\begin{array}{c}-0.205^{* * *} \\
(0.025)\end{array}$ & & $\begin{array}{c}-0.172 * * * \\
(0.022)\end{array}$ & & $\begin{array}{c}-0.794 * * * \\
(0.013)\end{array}$ \\
\hline RTN & & $\begin{array}{c}0.019 \\
(0.012)\end{array}$ & & $\begin{array}{c}0.014 \\
(0.017)\end{array}$ & & $\begin{array}{l}-0.001 \\
(0.008)\end{array}$ \\
\hline $\mathrm{B} / \mathrm{M}$ & & $\begin{array}{c}-0.269 * * * \\
(0.053)\end{array}$ & & $\begin{array}{c}-0.233^{* * *} \\
(0.065)\end{array}$ & & $\begin{array}{l}-0.038 \\
(0.042)\end{array}$ \\
\hline Time effect & Yes & Yes & Yes & Yes & Yes & Yes \\
\hline $\mathrm{AR}(1)$ & 0.000 & 0.000 & 0.000 & 0.000 & 0.000 & 0.000 \\
\hline $\mathrm{AR}(2)$ & 0.702 & 0.169 & 0.796 & 0.518 & 0.837 & 0.670 \\
\hline Hansen & 0.165 & 0.198 & 0.188 & 0.298 & 0.101 & 0.278 \\
\hline Diff-Hansen & 0.635 & 0.732 & 0.252 & 0.858 & 0.678 & 0.252 \\
\hline Instruments & 181 & 177 & 163 & 177 & 143 & 177 \\
\hline Firms & 190 & 190 & 189 & 189 & 190 & 190 \\
\hline Firm-years & 2456 & 2456 & 2456 & 2456 & 2489 & 2489 \\
\hline
\end{tabular}


Table 4(continued)

\begin{tabular}{|c|c|c|c|c|c|c|}
\hline \multicolumn{7}{|c|}{ Panel C: IV measured using CAPM Model - EPS } \\
\hline & \multicolumn{2}{|c|}{ Low Foreign } & \multicolumn{2}{|c|}{ Mid Foreign } & \multicolumn{2}{|c|}{ High Foreign } \\
\hline $\log \operatorname{IV}(\mathrm{t}-1)$ & $\begin{array}{c}0.317 * * * \\
(0.035)\end{array}$ & $\begin{array}{c}0.190 * * * \\
(0.040)\end{array}$ & $\begin{array}{c}0.301 * * * \\
(0.036)\end{array}$ & $\begin{array}{c}0.163 * * * \\
(0.037)\end{array}$ & $\begin{array}{c}0.298 * * * \\
(0.037)\end{array}$ & $\begin{array}{c}0.221 * * * \\
(0.039)\end{array}$ \\
\hline $\log$ CFIV & $\begin{array}{c}0.153 * * * \\
(0.022)\end{array}$ & $\begin{array}{c}0.058 * * \\
(0.028)\end{array}$ & $\begin{array}{c}0.202 * * * \\
(0.028)\end{array}$ & $\begin{array}{c}0.122 * * * \\
(0.023)\end{array}$ & $\begin{array}{c}0.289 * * * \\
(0.033)\end{array}$ & $\begin{array}{c}0.209 * * * \\
(0.024)\end{array}$ \\
\hline $\log \mathrm{TR}$ & & $\begin{array}{c}0.168 * * * \\
(0.032)\end{array}$ & & $\begin{array}{c}0.202 * * * \\
(0.035)\end{array}$ & & $\begin{array}{c}0.174 * * * \\
(0.046)\end{array}$ \\
\hline $\log$ Size & & $\begin{array}{c}-0.221 * * * \\
(0.026)\end{array}$ & & $\begin{array}{c}-0.172 * * * \\
(0.025)\end{array}$ & & $\begin{array}{c}-0.084 * * * \\
(0.012)\end{array}$ \\
\hline RTN & & $\begin{array}{c}0.008 \\
(0.011)\end{array}$ & & $\begin{array}{c}0.013 \\
(0.018)\end{array}$ & & $\begin{array}{c}0.006 \\
(0.008)\end{array}$ \\
\hline $\mathrm{B} / \mathrm{M}$ & & $\begin{array}{c}-0.276 * * * \\
(0.054)\end{array}$ & & $\begin{array}{c}-0.226 * * * \\
(0.075)\end{array}$ & & $\begin{array}{c}-0.066 \\
(0.044)\end{array}$ \\
\hline Time effect & Yes & Yes & Yes & Yes & Yes & Yes \\
\hline $\operatorname{AR}(1)$ & 0.000 & 0.000 & 0.000 & 0.000 & 0.000 & 0.000 \\
\hline $\operatorname{AR}(2)$ & 0.853 & 0.390 & 0.793 & 0.446 & 0.363 & 0.234 \\
\hline Hansen & 0.135 & 0.208 & 0.122 & 0.207 & 0.158 & 0.175 \\
\hline Diff-Hansen & 0.992 & 0.748 & 0.450 & 0.525 & 0.425 & 0.137 \\
\hline Instruments & 181 & 177 & 163 & 177 & 97 & 141 \\
\hline Firms & 190 & 190 & 189 & 189 & 190 & 190 \\
\hline Firm-years & 2456 & 2456 & 2456 & 2456 & 2489 & 2489 \\
\hline
\end{tabular}

This table reports the results of the two-step System-GMM estimation for log value of firmspecific variations in returns (log IV) estimated using the CAPM model. We control for log value of cash flow shock(log CFIV), turnover ratio (log TR), firm size (log Size), leverage effect (RTN), and book-tomarket (B/M) effects. Sales per share (SPS), cash earning per share (CEPS), and earnings per share(EPS) are used to measure Cash flow shock. Figures in parenthesis are p-values based on Windmeiher (2005) corrected standard errors. $\mathrm{AR}(1)$ and $\mathrm{AR}(2)$ report $\mathrm{p}$-value for the test of the first and second order autocorrelation in the first-differenced residuals. The values reported for the Hansen test are the p-values for the null hypothesis of instrument validity. The Diff-Hansen reports the p-values for the additional level moment validity. * **, and *** represent the statistical significance of the coefficients at $10 \% .5 \%$, and $1 \%$ level. 
Table 5. Firm-specific variations in returns and fundamentals using FF3+Mom Model

\begin{tabular}{|c|c|c|c|c|c|c|}
\hline \multicolumn{7}{|c|}{ Panel A: IV measured using FF3+Mom Model - SPS } \\
\hline & \multicolumn{2}{|c|}{ Low Foreign } & \multicolumn{2}{|c|}{ Mid Foreign } & \multicolumn{2}{|c|}{ High Foreign } \\
\hline $\log \operatorname{IV}(\mathrm{t}-1)$ & $\begin{array}{c}0.270 * * * \\
(0.036)\end{array}$ & $\begin{array}{c}0.193 * * * \\
(0.039)\end{array}$ & $\begin{array}{c}0.284 * * * \\
(0.086)\end{array}$ & $\begin{array}{c}0.170 * * * \\
(0.038)\end{array}$ & $\begin{array}{c}0.274 * * * \\
(0.041)\end{array}$ & $\begin{array}{c}0.209 * * * \\
(0.037)\end{array}$ \\
\hline $\log$ CFIV & $\begin{array}{c}0.213 * * * \\
(0.032)\end{array}$ & $\begin{array}{c}0.132 * * * \\
(0.031)\end{array}$ & $\begin{array}{c}0.152 * * * \\
(0.040)\end{array}$ & $\begin{array}{c}0.133 * * * \\
(0.035)\end{array}$ & $\begin{array}{c}0.160 * * * \\
(0.036)\end{array}$ & $\begin{array}{c}0.134 * * * \\
(0.031)\end{array}$ \\
\hline $\log \mathrm{TR}$ & & $\begin{array}{c}0.126 * * * \\
(0.036)\end{array}$ & & $\begin{array}{c}0.230 * * * \\
(0.032)\end{array}$ & & $\begin{array}{c}0.220 * * * \\
(0.041)\end{array}$ \\
\hline $\log$ Size & & $\begin{array}{c}-0.188 * * * \\
(0.032)\end{array}$ & & $\begin{array}{c}-0.144 * * * \\
(0.029)\end{array}$ & & $\begin{array}{c}-0.074 * * * \\
(0.013)\end{array}$ \\
\hline RTN & & $\begin{array}{c}0.015 \\
(0.012)\end{array}$ & & $\begin{array}{c}0.017 \\
(0.018)\end{array}$ & & $\begin{array}{c}0.012 \\
(0.008)\end{array}$ \\
\hline $\mathrm{B} / \mathrm{M}$ & & $\begin{array}{c}-0.275 * * * \\
(0.062)\end{array}$ & & $\begin{array}{c}-0.188 * * * \\
(0.072)\end{array}$ & & $\begin{array}{l}-0.055 \\
(0.045)\end{array}$ \\
\hline Time effect & Yes & Yes & Yes & Yes & Yes & Yes \\
\hline $\mathrm{AR}(1)$ & 0.000 & 0.000 & 0.000 & 0.000 & 0.000 & 0.000 \\
\hline $\operatorname{AR}(2)$ & 0.749 & 0.750 & 0.177 & 0.661 & 0.769 & 0.562 \\
\hline Hansen & 0.174 & 0.201 & 0.136 & 0.355 & 0.143 & 0.262 \\
\hline Diff-Hansen & 0.696 & 0.590 & 0.668 & 0.613 & 0.457 & 0.214 \\
\hline Instruments & 121 & 177 & 121 & 177 & 97 & 141 \\
\hline Firms & 190 & 190 & 189 & 189 & 190 & 190 \\
\hline \multirow[t]{3}{*}{ Firm-years } & 2456 & 2456 & 2456 & 2456 & 2489 & 2489 \\
\hline & \multicolumn{6}{|c|}{ Panel B: IV measured using FF3+Mom Model - CEPS } \\
\hline & \multicolumn{2}{|c|}{ Low Foreign } & \multicolumn{2}{|c|}{ Mid Foreign } & \multicolumn{2}{|c|}{ High Foreign } \\
\hline $\log I V(t-1)$ & $\begin{array}{c}0.311 * * * \\
(0.034)\end{array}$ & $\begin{array}{c}0.202 * * * \\
(0.041)\end{array}$ & $\begin{array}{c}0.294 * * * \\
(0.036)\end{array}$ & $\begin{array}{c}0.168 * * * \\
(0.039)\end{array}$ & $\begin{array}{c}0.287 * * * \\
(0.038)\end{array}$ & $\begin{array}{c}0.220 * * * \\
(0.033)\end{array}$ \\
\hline $\log$ CFIV & $\begin{array}{c}0.185^{* * * *} \\
(0.027)\end{array}$ & $\begin{array}{c}0.094 * * * \\
(0.032)\end{array}$ & $\begin{array}{c}0.160 * * * \\
(0.037)\end{array}$ & $\begin{array}{c}0.151 * * * \\
(0.042)\end{array}$ & $\begin{array}{c}0.141 * * * \\
(0.042)\end{array}$ & $\begin{array}{c}0.156 * * * \\
(0.037)\end{array}$ \\
\hline $\log \mathrm{TR}$ & & $\begin{array}{c}0.138 * * * \\
(0.036)\end{array}$ & & $\begin{array}{c}0.186 * * * \\
(0.039)\end{array}$ & & $\begin{array}{c}0.241 * * * \\
(0.039)\end{array}$ \\
\hline $\log$ Size & & $\begin{array}{c}-0.210 * * * \\
(0.028)\end{array}$ & & $\begin{array}{c}-0.152 * * * \\
(0.026)\end{array}$ & & $\begin{array}{c}-0.073 * * * \\
(0.013)\end{array}$ \\
\hline RTN & & $\begin{array}{c}0.014 \\
(0.011)\end{array}$ & & $\begin{array}{c}0.021 \\
(0.017)\end{array}$ & & $\begin{array}{c}0.007 \\
(0.008)\end{array}$ \\
\hline $\mathrm{B} / \mathrm{M}$ & & $\begin{array}{c}-0.272 * * * \\
(0.056)\end{array}$ & & $\begin{array}{c}-0.222 * * * \\
(0.068)\end{array}$ & & $\begin{array}{l}-0.017 \\
(0.043)\end{array}$ \\
\hline \multicolumn{7}{|l|}{ Time effect } \\
\hline $\mathrm{AR}(1)$ & 0.000 & 0.000 & 0.000 & 0.000 & 0.000 & 0.000 \\
\hline $\operatorname{AR}(2)$ & 0.961 & 0.494 & 0.489 & 0.918 & 0.790 & 0.584 \\
\hline Hansen & 0.217 & 0.216 & 0.394 & 0.108 & 0.149 & 0.155 \\
\hline Diff-Hansen & 0.678 & 0.388 & 0.288 & 0.821 & 0.602 & 0.105 \\
\hline Instruments & 163 & 177 & 181 & 141 & 121 & 141 \\
\hline Firms & 190 & 190 & 189 & 189 & 190 & 190 \\
\hline Firm-years & 2456 & 2456 & 2456 & 2456 & 2489 & 2489 \\
\hline
\end{tabular}


Table 5(continued)

\begin{tabular}{|c|c|c|c|c|c|c|}
\hline \multicolumn{7}{|c|}{ Panel C: IV measured using FF3+Mom Model - EPS } \\
\hline & \multicolumn{2}{|c|}{ Low Foreign } & \multicolumn{2}{|c|}{ Mid Foreign } & \multicolumn{2}{|c|}{ High Foreign } \\
\hline $\log \operatorname{IV}(\mathrm{t}-1)$ & $\begin{array}{c}0.290 * * * \\
(0.033)\end{array}$ & $\begin{array}{c}0.203 * * * \\
(0.039)\end{array}$ & $\begin{array}{c}0.272 * * * \\
(0.036)\end{array}$ & $\begin{array}{c}0.158 * * * \\
(0.038)\end{array}$ & $\begin{array}{c}0.303 * * * \\
(0.037)\end{array}$ & $\begin{array}{c}0.231 * * * \\
(0.032)\end{array}$ \\
\hline $\log$ CFIV & $\begin{array}{c}0.167 * * * \\
(0.026)\end{array}$ & $\begin{array}{c}0.067 * * \\
(0.031)\end{array}$ & $\begin{array}{c}0.183^{* * * *} \\
(0.028)\end{array}$ & $\begin{array}{c}0.116^{* * *} * \\
(0.023)\end{array}$ & $\begin{array}{c}0.245^{* * *} * \\
(0.026)\end{array}$ & $\begin{array}{c}0.164 * * * \\
(0.023)\end{array}$ \\
\hline $\log \mathrm{TR}$ & & $\begin{array}{c}0.135 * * * \\
(0.036)\end{array}$ & & $\begin{array}{c}0.197 * * * \\
(0.033)\end{array}$ & & $\begin{array}{c}0.166 * * * \\
(0.035)\end{array}$ \\
\hline $\log$ Size & & $\begin{array}{c}-0.231 * * * \\
(0.027)\end{array}$ & & $\begin{array}{c}-0.153 * * * \\
(0.025)\end{array}$ & & $\begin{array}{c}-0.075 * * * \\
(0.011)\end{array}$ \\
\hline RTN & & $\begin{array}{c}0.006 \\
(0.011)\end{array}$ & & $\begin{array}{c}0.019 \\
(0.017)\end{array}$ & & $\begin{array}{c}0.007 \\
(0.008)\end{array}$ \\
\hline $\mathrm{B} / \mathrm{M}$ & & $\begin{array}{c}-0.282 * * * \\
(0.059)\end{array}$ & & $\begin{array}{c}-0.211 * * * \\
(0.067)\end{array}$ & & $\begin{array}{l}-0.057 \\
(0.045)\end{array}$ \\
\hline Time effect & Yes & Yes & Yes & Yes & Yes & Yes \\
\hline $\operatorname{AR}(1)$ & 0.000 & 0.000 & 0.000 & 0.000 & 0.000 & 0.000 \\
\hline $\operatorname{AR}(2)$ & 0.636 & 0.763 & 0.631 & 0.788 & 0.188 & 0.140 \\
\hline Hansen & 0.113 & 0.264 & 0.222 & 0.285 & 0.118 & 0.382 \\
\hline Diff-Hansen & 0.713 & 0.459 & 0.404 & 0.481 & 0.379 & 0.360 \\
\hline Instruments & 163 & 177 & 163 & 177 & 121 & 177 \\
\hline Firms & 190 & 190 & 189 & 189 & 190 & 190 \\
\hline Firm-years & 2456 & 2456 & 2456 & 2456 & 2489 & 2489 \\
\hline
\end{tabular}

This table reports the results of the two-step System-GMM estimation for log value of firmspecific variations in returns (log IV) estimated using the CAPM model. We control for log value of cash flow shock(log CFIV), turnover ratio (log TR), firm size (log Size), leverage effect (RTN), and book-tomarket (B/M) effects. Sales per share (SPS), cash earning per share (CEPS), and earnings per share(EPS) are used to measure Cash flow shock. Figures in parenthesis are p-values based on Windmeiher (2005) corrected standard errors. $\mathrm{AR}(1)$ and $\mathrm{AR}(2)$ report p-value for the test of the first and second order autocorrelation in the first-differenced residuals. The values reported for the Hansen test are the p-values for the null hypothesis of instrument validity. The Diff-Hansen reports the p-values for the additional level moment validity. *,*, and *** represent the statistical significance of the coefficients at $10 \% .5 \%$, and $1 \%$ level. 